\title{
トルシア形高力ボルトを用いた摩擦接合により一体化した 鋼木複合断面軸力材の曲げ特性 \\ BENDING PROPERTIES OF STEEL-TIMBER COMPOSITE AXIAL MEMBERS FORMED WITH FRICTION-TYPE CONNECTIONS USING TORSHEAR-TYPE HIGH-STRENGTH BOLTS
}

\author{
遠藤俊貴*1, 高木 次郎*2, 荒木慶一*3, 見波 進 ${ }^{* 4}$, 十時 哲*5 \\ Toshiki ENDO, Jiro TAKAGI, Yoshikazu ARAKI, \\ Susumu MINAMI and Tetsu TOTOKI
}

\begin{abstract}
Although timber structures are advantageous for their cost and fabrication, there is a difficulty in obtaining large members and assuring strength in joints. Composite section members with steel plates sandwiched with timber sections can overcome these disadvantages; however, an effective method is required for their connection. In this research, a simple shear (friction type) connection using torshear-type bolts is developed and the connection properties are experimentally examined. Also, the buckling strength of the composite members is analytically evaluated using the obtained test data. Furthermore, relaxation of the bolt tension due to drying shrinkage and creep in timber was examined for 180 days.

The initial shear stiffness of the connection (tested one day after bolting) is $50-75 \mathrm{kN} / \mathrm{mm}$, while the first peak strength is greater than $20 \mathrm{kN}$. The relaxation of the stiffness is limited (the initial shear stiffness is $57-86 \mathrm{kN} / \mathrm{mm}$, and the first peak strength is $29-43 \mathrm{kN}$ ); however, the tension in bolts and the peak strength are degraded to $20 \%$ and $40 \%$, respectively. Analytical evaluation reveals that the connection failure does not control the buckling strength of the composite members.
\end{abstract}

Keywords : Steel-timber composite member, Friction-type connection, Torshear-type high-strength bolts, Shear stiffness of connections, Buckling strength, Bending stiffness 鋼木複合断面，摩擦接合，トルシア形高力ボルト，接合部せん断岡性，座屈而力，曲け岡性

1. 序

木質構造には，コンクリート構造や鉄骨構造と比べて，経済性に 優れること，加工性と施工性が高いこと，自然素材として仕上げを 兼用できること，二酸化炭素排出量削減効果を持つことなどの多く の長所がある。一方，他の構造と比べて，部材寸法に関する制約が 大きいこと, 品質のばらつきが大きいこと, 接合部の強度確保が困 難なことなどの短所を持つ。上記の短所を補う目的で集成材が使用 されているが，接合部の強度確保が難しい点や，無垢の製材と比較 して高価である点に課題が残る。

我が国では戦後に大量に植樹されたスギ材が大量伐採期にあり, 間伐材を含めた木材が余剩傾向にあることから，国内産スギ材の有 効活用が強く望まれている。しかし，これらのスギ材は輸入材を含 む他木材と比べて剛性や耐力が低く, 安定した断面寸法を得ること が難しいこともあり，十分に活用されていない。
このような背景から，地場産業の活性化や資源の有効利用を目的 として，木材と鋼材を組み合わせた複合断面部材に関する研究が進 められている ${ }^{1-7)}$ 。鋼木複合構造の長所として，鋼材を他部材との 接合に利用することで安定した接合部性能を確保できること，比較 的小断面の木材についても鋼材との組み合せで大断面化が可能にな ることが挙げられる。

鋼木複合断面構造を実現する上で，最も大きな課題となるのが木 材と鋼材を一体化する接合方法である。楠ら ${ }^{1-3)}$ は接着剤，スタッ ド，高力ボルトなどを用いた接合方法による鋼木複合断面軸力材に ついて実験による性能評価を行い，スギ材による鋼板の座屈補剛の 有効性を示した。坂田ら ${ }^{4-7)}$ はシアリングや摩擦接合型コネクタを 用いた接合方法による複合断面部材の軸圧縮時力学的挙動を明らか にし，接合部の二面せん断試験から得られたせん断剛性を用いる耐 力評価法を提案した。しかし，これらの一体化接合方法は，加工性
*1 日本学術振興会特別研究員 DC 大学院生 $\cdot$ 工修 (京都大学大学院工学研究科建築学専攻)

*2 首都大学東京都市環境学部建築都市コース 准教授・Ph. D.

$* 3$ 京都大学大学院工学研究科建築学専攻 准教授・博士 (工学)

*4 首都大学東京都市環境学部建築都市コース 助教・博士 (工学)

* 5 首都大学東京都市環境学部建築都市コース 学部学生
Graduate Student, Research Fellow of the Japan Society for the Promotion of Science, M. Eng.

(Dept. of Architecture and Architectural Eng., Kyoto Univ.)

Assoc. Prof., Div. of Architecture and Urban Studies, Tokyo Metropolitan Univ, Ph. D.

Assoc. Prof., Dept. of Architecture and Architectural Eng., Kyoto Univ., Dr. Eng. Assistant Prof., Div. of Architecture and Urban Studies, Tokyo Metropolitan Univ., Dr. Eng.

Bachelor Student, Div. of Architecture and Urban Studies, Tokyo Metropolitan Univ. 
と経済性の面で課題がある。

本論文では，トルシア形高力ボルトを用いた，簡便な木材と鋼材 間の接合方法を提案し, 鋼板通し材を 2 本の木材通し材で挟み込み, 提案接合法を用いて一体化した鋼木複合断面軸力材の性能を解析的 に評価する。はじめに, 提案接合部のせん断特性と, 提案接合方法 を用いて構成した複合断面軸力材の曲げ特性を実験により評価する。 また時間経過によるボルト張力の低下が接合部や部材としてのせん 断特性や曲げ特性に及ぼす影響についても実験による検討を行う。 次に, 複合断面部材の数值モデルを作成し, 弾性座屈耐力の評価を 行う。

\section{2. 提案鋼木複合断面軸力材の概要}

本論文で提案するトルシア形高力ボルトを用いた鋼木間の摩擦接 合法の概要を図 1 に示す。複合断面は，鋼板を木材で挟む形で構成 する。座掘錐により木材に座掘穴を設け，ボルトで挟み込む木材厚 を薄くすると同時に, ボルトの頭やナットを隠す構造とする。トル シア形高力ボルトで締付けると座金が木材にめり込むが, 次章で述 べるように圧縮ひずみ度が $50 \%$ 超える領域では，木材の間隙率の 低下により剛性と強度が再上昇寸ることから，トルシア形高力ボル トのピンテールが破断するまでの張力導入を可能とする点が提案接 合方法の特徴である。

提案摩擦接合法により，木材と鋼板とを緊結することで，鋼材の 高い強度を利用しつつ，木材をその座屈補剛としながら断面性能に 寄与させた複合断面部材が構成できる。木質構造の一部に本複合断 面部材を利用する場合には，木質部材との接合に一般的な木造用接 合金物を用いることができるほか，耐震壁に構造用合板を用いる場 合などにも，釘を用いた固定方法が可能であり，従来の木質構造と の相性もよい。さらに, 鋼木複合断面部材同士の接合には断面内の 鋼板同士を木材部分から突出させ，高力ボルトで接合することが可 能である。これにより一般の木材同士の接合よりも剛に近い形で接 合でき, ラーメン架構を容易に構成できる。

鋼木複合断面軸力材の設計では，座屈耐力の評価が重要になる。 図 2 に示寸軸力材の断面構成では，同図中の強軸（X 軸）まわりの

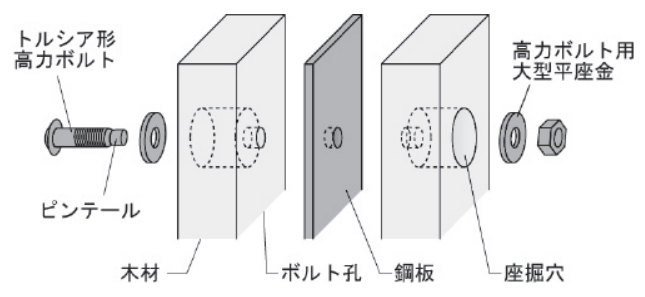

図 1 複合断面の接合部構成
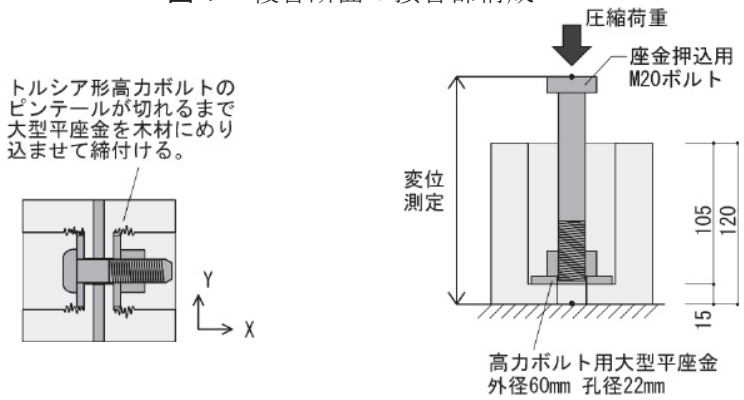

図 2 複合断面一体化方法

図 3 めり込夕圧縮実験方法
弾性座屈耐力については，鋼材と木材のそれぞれの耐力の和で与え られる。一方, 弱軸（Y 軸）まわりについては，一体化接合部のせ 几断剛性（鋼材面と木材面のずれに対する剛性），接合位置，接合部 の数に応じて座屈耐力が決定される。そこで，本論文では弱軸まわ りの曲げ岡性を評価するための基礎的な検討を行う。

\section{3. 接合部を想定したスギ材のめり込み圧縮実験}

\section{1. 実験の目的と概要}

トルシア形高力ボルトで木材を締付けた場合のボルト張力とめり 込みによる木材のひずみの関係を調べることを目的として，図 3 に 示すめり込み圧縮実験を行った。試験体は, 一辺が $120 \mathrm{~mm}$ の立方体 のスギ材で，繊維と直交方向（R 方向）に深さ $105 \mathrm{~mm}$ ，直径 $65 \mathrm{~mm}$ の 座掘穴を設け，さらにそれを延長する形で，直径 $22 \mathrm{~mm}$ のボルト孔を 反対面まで貫通させた。座掘穴を上面にして，穴底に直径 $60 \mathrm{~mm} ， 孔$ 径 $22 \mathrm{~mm}$ ，厚さ $6 \mathrm{~mm}$ の高力ボルト用の大型座金を置き，これを鉛直下 方向に押し込む形で座金下の木材（以下，木材圧縮部分と呼ぶ）に 圧縮力を加えた。ボルトの圧縮変形は木材の圧縮変形より十分に小 さいとして，ボルト頭部の鉛直変位を木材めり込み深さと考えた。 圧縮応力度と木材圧縮部分のひずみ度の関係を図 4 に示す。ここで の圧縮応力度は圧縮荷重を座金面積で除した值である。ひずみ度は 木材めり込み深さを元の厚さの $15 \mathrm{~mm}$ で除した平均ひずみ度である。 載荷は圧縮力が $200 \mathrm{kN}$ になるまで（木材圧縮部分のひずみ度が $75 \%$ 程度に至るまで）実施した。

\section{2. 実験結果}

繊維と直交方向の普通構造スギ材の材中間部のめり込みに対する 部分圧縮基準材料強度は $6.0 \mathrm{~N} / \mathrm{mm}^{2}$ であり ${ }^{8)}$ ，本実験でも圧縮応力度 が部分圧縮強度に至るまでは弾性挙動を示した。ひずみ度が $1.5 \%$ の 時の割線剛性として定義した初期剛性 $E_{0}$ は $355 \mathrm{~N} / \mathrm{mm}^{2}$ であった。圧 縮応力度が $8 \mathrm{~N} / \mathrm{mm}^{2}$ 付近（ひずみ度が $3 \%$ 付近）より大きくなると， めり込みが進行し塑性変形が顕著になり，接線剛性が大きく低下し た。ひずみ度 $11 \%$ 付近で，接線剛性は最低值の $8 \mathrm{~N} / \mathrm{mm}^{2}$ をとるが，そ の後, 変形の進行に伴い, 耐力と剛性は単調に増加した。ひずみ度 が 70\%付近の剛性は初期剛性とほぼ同值であり，この時の圧縮応力 度は部分圧縮強度の 12.5 倍の $75 \mathrm{~N} / \mathrm{mm}^{2}$ となった。

S10T のトルシア形高力ボルト M20 の場合，ピンテールが破断する ときのボルト張力は 170 から $210 \mathrm{kN}^{9)}$ である。図 4 から木材圧縮部 分のひずみ度 $75 \%$ 程度まで締付けることにより, トルシア形高力ボ ルトを用いた締付が可能になると考えられる。

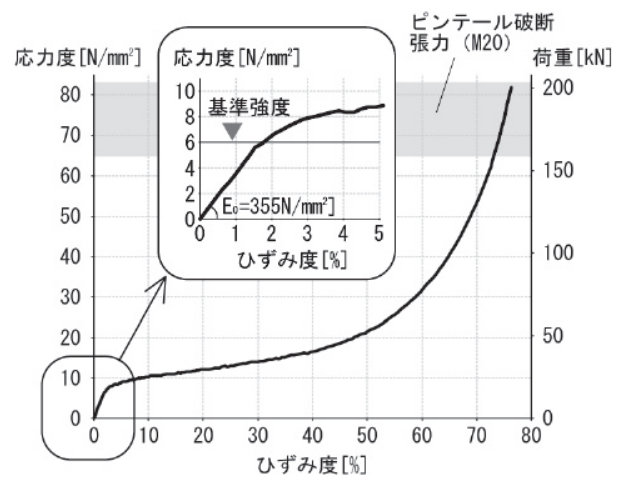

図4 圧縮応力度一ひずみ度関係 
試験体の実験前の含水率は 19.3\%であり，木材圧縮部分がひずみ 度 $75 \%$ まで圧縮される前後の比重は, それぞれ 0.45 と 1.20 であっ た。スギ材の真比重 (全乾状態での細胞壁実質部の比重) $1.50^{10)}$, 含水率を不変と仮定した場合の実験前後の間隙率を計算すると, そ れぞれ $68 \%$ と $13 \%$ になることから，ひずみ度 $75 \%$ までの圧縮により， 比重は約 2.5 倍に増大し, 間隙率は約 0.2 倍に低下したことになる。

\section{4. 接合部のせん断実験}

\section{1 . 実験の目的と概要}

トルシア形高力ボルトを用いた鋼木複合断面部材の摩擦接合部の せん断特性を実験により検討する。さらに, 時間経過によるボルト 張力の低下が接合部のせん断特性に及ぼす影響を調査する。

複合断面軸力材に軸力が作用し座屈に至る曲げ変形が進行すると, 一体化接合部において鋼板と木材の間でせん断変形（ずれ）が生じ る。本論では曲げ変形に対応させて, 二面せん断実験ではなく一面 せん断実験により接合部のせん断特性を調査する。なお，ボルトの ロープ効果を避けることも一面せん断実験を行う主な理由の一つで ある。

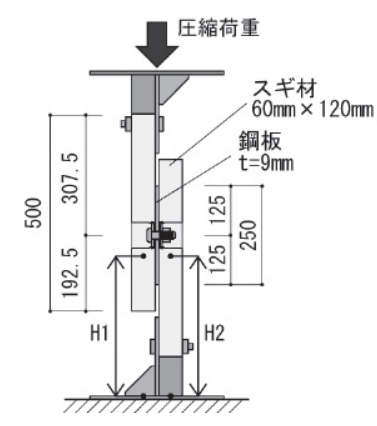

図 5 接合部せん断実験概要

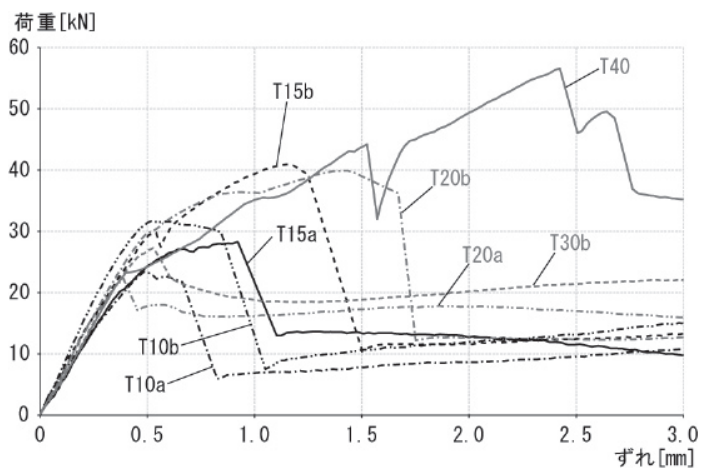

\section{2. 試験体と載荷・計測方法}

試験体の概要を図 5 および図 6 に示す。 $9 \mathrm{~mm} \times 120 \mathrm{~mm} \times 250 \mathrm{~mm}$ の SS400 の鋼板を $60 \mathrm{~mm} \times 120 \mathrm{~mm} \times 500 \mathrm{~mm}$ のスギ材で挟み，トルシア形高 カボルト（S10T，M20）で座金を木材 R 方向にめり込ませて締付ける ことで一体化した。この試験体の断面寸法は在来軸組工法角柱断面 寸法を参考に決定した。鋼板表面は黒皮仕上げとした。座掘穴底の 木材厚さ $a$ をパラメータとし， 5 種類， 2 体ずつ（ $a=40 \mathrm{~mm}$ のみ 1 体） の試験体について実験を行った。表 1 に試験体一覧を示す。なお, 穴底木材厚さ $a$ が $20 \mathrm{~mm}$ 以上の場合は, ボルト締付けによるめり込み 量が大きくなり，既製のトルシア形高力ボルトではねじ山長さ（M20 トルシア形高力ボルトは $35 \mathrm{~mm} ）$ が不足するため，木材圧縮部分にあ らかじめ載荷機で圧縮変形を与えてからトルシア形高力ボルトで締 付けた。なお穴底厚さ $a$ が $30 \mathrm{~mm}$ の試験体 T30b は木材圧縮部分にあ らかじめ圧縮変形を与えた際に，はしあき部分に繊維方向に割裂が 生じた。ボルトにはひずみゲージを貼付し，事前に行った校正実験 との比較によりボルト張力を測定した。ボルト締付け直後はボルト 張力が安定しないため, 締付けから載荷するまでに 18 時間程度の時 間を置いて載荷した。載荷は $0.05 \mathrm{~mm} / \mathrm{sec}$ の変位制御で行った。図 5 に示すように鋼板を挟む両側の木材の鉛直方向変位 $H_{1}, H_{2}$ を計測し， 木材と鋼板のずれ $\Delta$ を式(1)で算出した。

$$
\Delta=\frac{H_{1}-H_{2}}{2}
$$

$H_{1}, H_{2}$ は木材表面の鉛直変位を測定しているため, 断面が平面保持 していない可能性を考慮すると， れを直接評価できていないことも考えられる。しかし，鋼木間のず れを直接計測することは困難であるため，便宜的に $\Delta$ を鋼木間のず れとして扱う。荷重と $\Delta$ の関係より接合部のせん断剛性とせん断耐 力を算出する。

\section{3. 実験結果}

実験結果を表 1 に示す。図 6 に示すめり込み後の木材めり込み深 さ $b$ を座掘穴底の木材厚さ $a$ で除して，木材圧縮部分の平均ひずみ 度 $\varepsilon$ を算出した。全ての試験体において $\varepsilon$ は $70 \%$ 前後と安定してい たが, ボルトの初期導入張力 $T_{0}$ および実験時張力 $T_{1}$ にはばらつきが 生じた。鋼材の接合に使用寸る場合, M20 トルシア形高力ボルトの ピンテール破断時の張力は $170 〜 210 \mathrm{kN}^{9)}$ であるが，木材をめり込 み圧縮させる本実験の場合は破断時直後の張力が $100 \mathrm{kN}$ まで低下し 得ることが確認された。ただし，4．5．節の結果も含めると，最 低でも $60 \mathrm{kN}$ 以上の初期張力導入が可能であることが確認された。図

図 7 接合部せん断実験 荷重一ずれ関係

表 1 接合部せん断実験 試験体一覧

\begin{tabular}{|c|c|c|c|c|c|c|c|c|c|c|c|c|c|c|c|c|c|c|}
\hline \multirow{2}{*}{$\begin{array}{l}\text { 試験体 } \\
\text { 番号 }\end{array}$} & \multirow{2}{*}{$\begin{array}{c}\rho^{* 1)} \\
{\left[\mathrm{g} / \mathrm{cm}^{3}\right]}\end{array}$} & \multirow{2}{*}{$\begin{array}{l}\mathrm{u}^{* 1)} \\
{[\%]}\end{array}$} & \multirow{2}{*}{$\begin{array}{c}\mathrm{a}^{* 1)} \\
{[\mathrm{mm}]}\end{array}$} & \multirow{2}{*}{$\begin{array}{l}\mathrm{b}^{* 1)} \\
{[\mathrm{mm}]}\end{array}$} & \multirow{2}{*}{$\begin{array}{l}\varepsilon^{* 1)} \\
{[\%]}\end{array}$} & \multirow{2}{*}{$\begin{array}{c}\mathrm{T}_{0} \\
{[\mathrm{kN}]}\end{array}$} & \multirow{2}{*}{$\begin{array}{c}\mathrm{T}_{1} \\
{[\mathrm{kN}]}\end{array}$} & \multirow{2}{*}{$\begin{array}{c}\mathrm{T}_{1} / \mathrm{T}_{0} \\
{[\%]}\end{array}$} & \multirow{2}{*}{$\begin{array}{c}\mathrm{T}_{\mathrm{h}} \\
{[\mathrm{h}]}\end{array}$} & \multicolumn{5}{|c|}{ せん断剛性*2) $[\mathrm{kN} / \mathrm{mm}]$} & \multirow{2}{*}{$\begin{array}{r}Q_{\mathrm{d}} \\
{[\mathrm{kN}]}\end{array}$} & \multirow{2}{*}{$\begin{array}{c}Q_{\max } \\
{[\mathrm{kN}]}\end{array}$} & \multirow{2}{*}{$\begin{array}{l}\text { 破壊 } \\
\text { 形状 }\end{array}$} & \multirow{2}{*}{ 備考 } \\
\hline & & & & & & & & & & $5 \mathrm{kN}$ & 7. $5 \mathrm{kN}$ & $10 \mathrm{kN}$ & $15 \mathrm{kN}$ & $20 \mathrm{kN}$ & & & & \\
\hline T10a & 0.377 & 22 & 10.8 & 7.1 & 66 & 110 & 58 & 53 & 16.7 & 69 & 64 & 60 & 55 & 51 & 23 & 23 & $\mathrm{i}$ & \\
\hline $\mathrm{T} 10 \mathrm{~b}$ & 0.408 & 26 & 10.9 & 7.4 & 68 & 161 & 96 & 59 & 18.1 & 73 & 74 & 75 & 76 & 74 & 32 & 32 & ii & \\
\hline T15a & 0.358 & 21 & 15.0 & 11.0 & 73 & 144 & 80 & 55 & 18.5 & 53 & 53 & 56 & 56 & 54 & 27 & 28 & $\mathrm{i}$ & \\
\hline $\mathrm{T} 15 \mathrm{~b}$ & 0.420 & 24 & 15.6 & 10.4 & 67 & - & - & - & 17.9 & 69 & 69 & 68 & 65 & 62 & 30 & 41 & ii & $\begin{array}{l}\text { 締付け時にひず } \\
\text { みゲージ破断 }\end{array}$ \\
\hline T20a & 0.384 & 23 & 20.1 & 14.4 & 72 & 138 & 93 & 68 & 17.6 & 63 & 63 & 66 & 65 & 60 & 22 & 22 & $\mathrm{i}$ & \\
\hline $\mathrm{T} 20 \mathrm{~b}$ & 0.436 & 25 & 19.6 & 14.2 & 72 & 124 & 60 & 48 & 17.7 & 60 & 62 & 65 & 65 & 64 & 36 & 40 & ii & \\
\hline T30a & 0.404 & 22 & 30.1 & 21.3 & 71 & 126 & 67 & 53 & 18.0 & - & - & - & - & - & 35 & 47 & ii & 変位計測失敗 \\
\hline $\mathrm{T} 30 \mathrm{~b}$ & 0.432 & 33 & 29.6 & 22.0 & 74 & 161 & 84 & 52 & 17.9 & 52 & 56 & 59 & 60 & 61 & 27 & 27 & ii & $\begin{array}{l}\text { 接合部加圧時に } \\
\text { 木材割裂発生 }\end{array}$ \\
\hline T40 & 0.414 & 28 & 40.2 & 27.5 & 68 & 101 & 52 & 51 & 18.2 & 56 & 57 & 58 & 59 & 60 & 43 & 57 & ii & \\
\hline
\end{tabular}

$\rho:$ 木材密度, $\mathrm{u}:$ 木材含水率, $\mathrm{a}:$ 座掘穴底の木材厚さ, $\mathrm{b}:$ 木材めり込み深さ, $\varepsilon:$ ひずみ度 $(\varepsilon=b / a), \mathrm{T}_{0}:$ 初期導入張力, $\mathrm{T}_{1}:$ 実験時張力（張力導入から 1 日後）,

$t_{\mathrm{h}}$ : ボルト締付けから載荷までの時間, $Q_{d}$ : 荷重降下点, $Q_{\max }$ : 最大せん断耐力

$* 1)$ 木材の諸值は全て 2 本の平均とした。*2) せん断剛性は原点と各荷重時の点を結んだ割線剛性として求めた。*3) 破壊形状 : 図 8 の ( i ), (ii) を示す。 
7 に木材面一面と鋼板面に作用する荷重とずれ $\Delta$ の関係を示す。 5 , 7. 5，10，15，20kN 耐力時のそれぞれの割線からせん断岡性を算出 した。20kN 耐力時のせん断剛性は 51〜 74kN/mm（平均 $61 \mathrm{kN} / \mathrm{mm}$ ）で あり, 穴底厚さ $a$ が約 $10 \mathrm{~mm}$ から $40 \mathrm{~mm}$ までの範囲では, 穴底厚さa とせん断剛性に相関関係は見られなかった。なお、これの根拠は明 確でないため、接合部の力学的メカニズムの更なる検討が今後必要 である。変位制御載荷中に初めて荷重が降下した点を荷重降下点 $Q_{\mathrm{d}}$ とすると， $Q_{\mathrm{d}}$ は 22〜 43kN であり，最低值でも $20 \mathrm{kN}$ 以上となった。 最大せん断耐力は $22 \sim 57 \mathrm{kN}$ となった。また, 破壊形状については(i) 支圧周辺部破断と（ii）はしあき破断の 2 種類が確認された(図 8 )。 実験結果より, 穴底厚さ a が大きくなると荷重降下点および最大せ 儿断耐力は上昇し, 穴底厚さ $a$ が $30 \mathrm{~mm}$ 以上の試験体 T30a, T30b, T40 のように，はしあき破断する傾向が観察された（表 1 ）。

\section{4. 破壊形状の力学的考察}

接合部の破壊形状を簡易な力学モデルを用いて考察する。写真 1 にボルト締め付け後の接合部断面写真を示す。接合部はボルトの締 め付けにより R 方向に繊維が切断されている部分(繊維切断層)と, めり込み変形が生じている部分 (めり込み層)に区分できる(図 9)。 せん断実験時に支圧部周辺破断が生じる場合も，はしあき破断が生 じる場合も, 繊維切断層とめり込み層の境界付近からせん断破壊が 進行していくと考えられる。繊維切断層の厚さをめり込み深さ $b$ の $s$ 倍 $(0<s<1)$ とすると, 破断時のモデルは図 10 のように簡易的に モデル化できる。なお図中 $L$ ははしあき距離, $\mathrm{R}$ は座掘り穴径とし, それぞれ $192.5 \mathrm{~mm}, 65 \mathrm{~mm}$ とする。いま無等級スギ材の圧縮, 引張, せん断強度をそれぞれ $F_{c}, F_{t}, F_{S}\left(F_{c}=18.0 \mathrm{~N} / \mathrm{mm}^{2}, \quad F_{t}=10.8 \mathrm{~N} / \mathrm{mm}^{2}\right.$, $\left.F_{S}=1.8 \mathrm{~N} / \mathrm{mm}^{2}\right)^{8)}$ とすると, 図 10 より支圧部周辺破断時の強度 $F_{1}$ およびはしあき破断時の強度 $F_{2}$ は次式で表せる。

$$
F_{1}=\left(F_{t}+F_{c}+2 F_{s}\right)(a-s b) R
$$

$F_{2}=F_{t}(a-s b) R+2 F_{s}(a-s b)(L+R / 2)+F_{s} R(L-R / 2)$

パラメータ $S$ の值は写真 1 に示寸試験体のように概称めり込み深 さ $b$ の $1 / 2$ であった。このため $s=0.5$ と仮定し, この場合の最大せ 几断力 $-(a-s b)$ 関係を図 11 に示寸。図中@印は支圧部周辺破断が

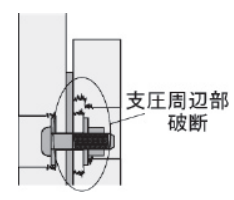

（i）支圧部周辺破断

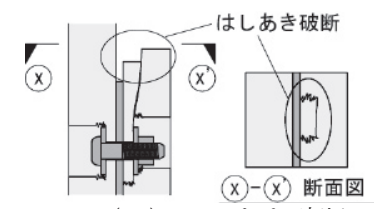

(ii）はしあき破断
図 8 接合部せん断実験破壊形状
生じた試験体，印印ははしあき破断が生じた試験体，×印は実験前 に割裂が生じていたために耐力が小さかったと思われる試験体 （T30b）を示す。また破線に支圧部周辺破断時の理論強度 $F_{1}$ を，一 点鎖線にはしあき破断の理論強度 $F_{2}(L=192.5 \mathrm{~mm}$ の場合）を示寸。 実験は穴底厚さ a が $10 \mathrm{~mm}$ から $40 \mathrm{~mm}$ の範囲で行っており，実験結果

（表 1） より， $b \fallingdotseq 2 a / 3$ なので $a-s b \fallingdotseq 2 a / 3 （ s=0.5$ とする）と仮定 し, 理論值の横軸の範囲は $6.7 \mathrm{~mm}$ から $26.7 \mathrm{~mm}$ とする。 $a^{-} s b$ が $6.7 \mathrm{~mm}$ から $26.7 \mathrm{~mm}$ の範囲で $F_{1}<F_{2}$ であり，理論的には支圧部周辺破断が 卓越するが，実験結果の破壊形状は安定して予測できていない。こ れは, 本試験の試験体パラメータから算出される $F_{1}$ と $F_{2}$ の差は 1.0 から $13.9 \mathrm{kN}$ であり，木材の強度のばらつきに対して $F_{1}$ と $F_{2}$ の差が 小さいことが一因と考えられる。一方で，各破壊形状に対する最大 せん断耐力は概ね予測できているといえる（図 11）。二点鎖線に $L=300 \mathrm{~mm}$ の場合におけるはしあき破断の理論值を示す。 $F_{2}$ は $L=192.5 \mathrm{~mm}$ のときと比較して, $1.3 \sim 1.5$ 倍大きくなる。一方で, $F_{1}$ は $L$ に依らず一定であり， はしあき距離 $L$ を大きくすれば $F_{1}$ と $F_{2}$

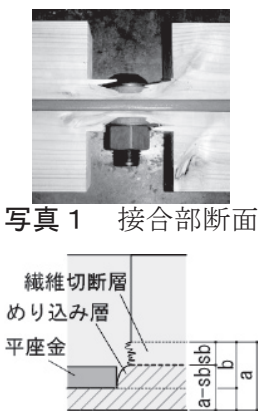

図 9 接合部断面

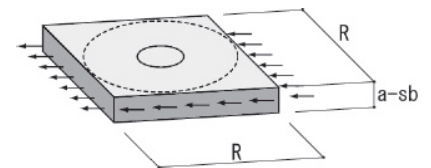

(i) 支圧部周辺破断

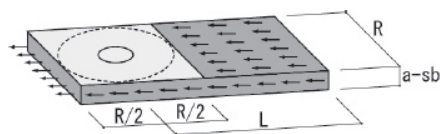

（ii）はしあき破断

図 10 簡易力学モデル

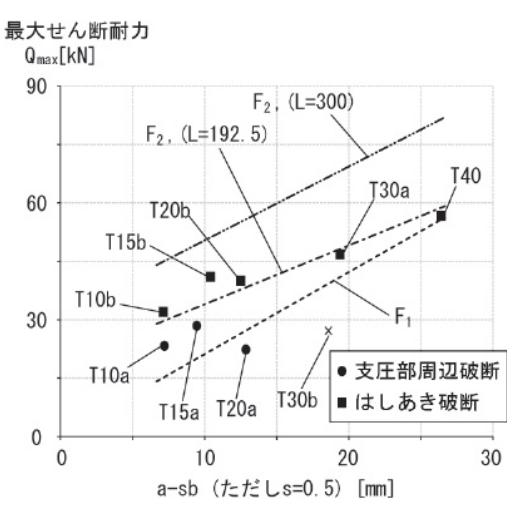

図 11 最大せん断耐力一 $(a-s b)$ 関係

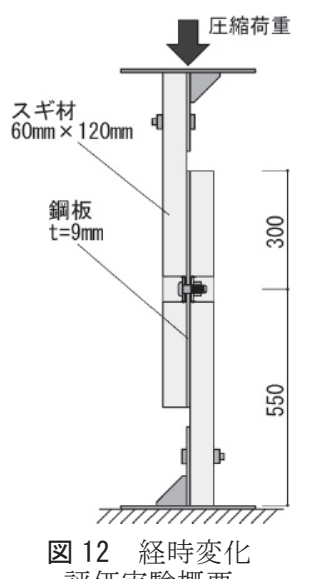

詊価䒠験概要

表 2 経時変化評価実験 試験体一覧 $\mathrm{K} 1 \sim \mathrm{K} 6$

\begin{tabular}{|c|c|c|c|c|c|c|c|c|c|c|c|c|c|c|c|c|c|}
\hline \multirow{2}{*}{$\begin{array}{c}\text { 試験体 } \\
\text { 番号 }\end{array}$} & \multirow{2}{*}{$\begin{array}{c}\rho^{* 1)} \\
{\left[\mathrm{g} / \mathrm{cm}^{3}\right]}\end{array}$} & \multirow{2}{*}{$\begin{array}{l}\mathrm{u}^{* 4)} \\
{[\%]}\end{array}$} & \multirow{2}{*}{$\begin{array}{l}\mathrm{a}^{* 1)} \\
{[\mathrm{mm}]}\end{array}$} & \multirow{2}{*}{$\begin{array}{l}\mathrm{b}^{* 11} \\
{[\mathrm{~mm}]}\end{array}$} & \multirow{2}{*}{$\begin{array}{l}\varepsilon^{* 1)} \\
{[\%]}\end{array}$} & \multirow{2}{*}{$\begin{array}{c}\mathrm{T}_{0} \\
{[\mathrm{kN}]}\end{array}$} & \multirow{2}{*}{$\begin{array}{c}\mathrm{T}_{\mathrm{t}} \\
{[\mathrm{kN}]}\end{array}$} & \multirow{2}{*}{$\begin{array}{c}\mathrm{T}_{\mathrm{t}} / \mathrm{T}_{0} \\
{[\%]}\end{array}$} & \multirow{2}{*}{$\begin{array}{c}\mathrm{t} \\
\text { [日] }\end{array}$} & \multicolumn{5}{|c|}{ せん断剛性 ${ }^{* 2)}[\mathrm{kN} / \mathrm{mm}]$} & \multirow{2}{*}{$\begin{array}{c}Q_{d} \\
{[k N]}\end{array}$} & \multirow{2}{*}{$\begin{array}{l}\mathrm{Q}_{\max } \\
{[\mathrm{kN}]}\end{array}$} & \multirow{2}{*}{$\begin{array}{l}\text { 破壞 } \\
\text { 形状33 }\end{array}$} \\
\hline & & & & & & & & & & $5 \mathrm{kN}$ & 7. $5 \mathrm{kN}$ & $10 \mathrm{kN}$ & $15 \mathrm{kN}$ & $20 \mathrm{kN}$ & & & \\
\hline K1 & 0.489 & $\overline{-}$ & 15.8 & 10.7 & 67 & 67 & 30 & 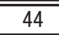 & 1 & 59 & 59 & 61 & 58 & 49 & 31 & 31 & $i$ \\
\hline K2 & 0.466 & - & 15.9 & 10.6 & 67 & 129 & 60 & 46 & 2 & 71 & 73 & 72 & 71 & 68 & 29 & 29 & $\mathrm{i}$ \\
\hline K3 & 0.503 & - & 15.7 & 10.5 & 67 & 81 & 34 & 42 & 4 & 67 & 68 & 65 & 62 & 57 & 24 & 32 & $\mathrm{i}$ \\
\hline K4 & 0.473 & - & 15.9 & 10.4 & 65 & 83 & 30 & 37 & 7 & 86 & 82 & 80 & 76 & 68 & 33 & 39 & $i$ \\
\hline K5 & 0.429 & - & 15.7 & 10.7 & 68 & 120 & 36 & 30 & 15 & 57 & 63 & 62 & 62 & 56 & 19 & 43 & $i$ \\
\hline K6 & 0.435 & - & 16.3 & 11.0 & 68 & 138 & 29 & 21 & 30 & 75 & 65 & 66 & 64 & 61 & 20 & 36 & $i$ \\
\hline K7 & 0.487 & - & 14.9 & 9.7 & 65 & 141 & 22 & 16 & 59 & 83 & 81 & 74 & 70 & 60 & 17 & 31 & $\mathrm{i}$ \\
\hline K8 & 0.483 & $-(15)$ & 15.9 & 11.7 & 74 & 169 & 12 & 7 & 177 & 76 & 78 & 70 & 28 & 19 & 12 & 29 & $i$ \\
\hline
\end{tabular}

表 3 経時変化評価実験 試験体一覧 $\quad K A \sim K C$

\begin{tabular}{|c|c|c|c|c|c|c|c|c|c|c|c|c|c|c|}
\hline \multirow{2}{*}{$\begin{array}{c}\text { 試験体 } \\
\text { 番号 }\end{array}$} & \multirow{2}{*}{$\begin{array}{c}\rho^{* 1)} \\
{\left[\mathrm{g} / \mathrm{cm}^{3}\right]}\end{array}$} & \multirow{2}{*}{$\begin{array}{l}\mathrm{u}^{* 4)} \\
{[\%]}\end{array}$} & \multirow{2}{*}{$\begin{array}{l}a^{* 11} \\
{[\mathrm{~mm}]}\end{array}$} & \multirow{2}{*}{$\begin{array}{l}\mathrm{b}^{* 1)} \\
{[\mathrm{mm}]}\end{array}$} & \multirow{2}{*}{$\begin{array}{l}\varepsilon^{* 1)} \\
{[\%]}\end{array}$} & \multirow{2}{*}{$\begin{array}{c}\mathrm{T}_{0} \\
{[\mathrm{kN}]}\end{array}$} & \multicolumn{8}{|c|}{ 7. $5 \mathrm{kN}$ 時のせん断剛性 ${ }^{* 2)}[\mathrm{kN} / \mathrm{mm}]$} \\
\hline & & & & & & & 1日後 & 2 日後 & 4 日後 & 7 日後 & 15 日後 & 30 日後 & 60 日後 & 180 日後 \\
\hline KA & 0.462 & $-(17)$ & 14.9 & 10.4 & 70 & 150 & 69.4 & $\begin{array}{l}74.3 \\
\end{array}$ & 73.6 & 72.5 & $\begin{array}{l}74.4 \\
\end{array}$ & 72.9 & 70.2 & 71.2 \\
\hline KB & 0.425 & $-(16)$ & 15.5 & 11.1 & 72 & 118 & 62.8 & 73.7 & 62.2 & 60.6 & 73.3 & 62.8 & 67.0 & 75.4 \\
\hline KC & 0.503 & $-(16)$ & 15.4 & 11.1 & 72 & 132 & 57.9 & 60.5 & 59.2 & 58.9 & 63.4 & 55.8 & 63.5 & 58.8 \\
\hline
\end{tabular}

实駼時镸力 (張力導 入から $\mathrm{t}$ 日後) $\mathrm{t}$ : ボル卜締付 けから載荷 までの日数 *4）「一」は計 測不備を 示す。括弧 内はボル 6 ヶ月後 の実験直 前の値を 示す。 


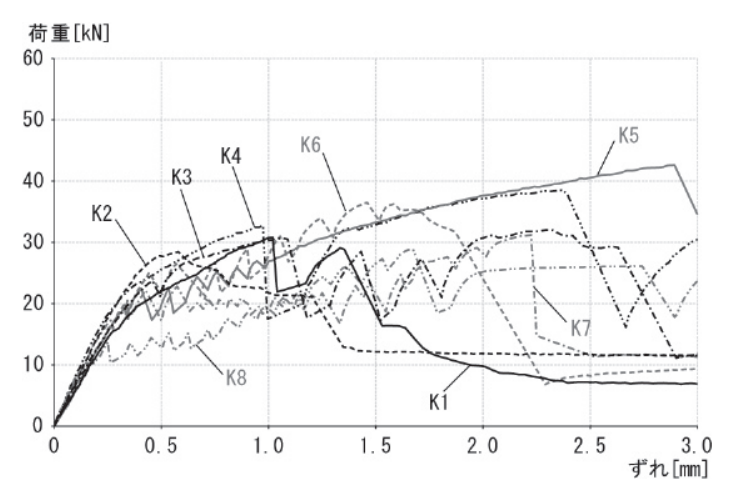

図 $13 \quad K 1 \sim K 8 \quad$ 荷重一ずれ関係

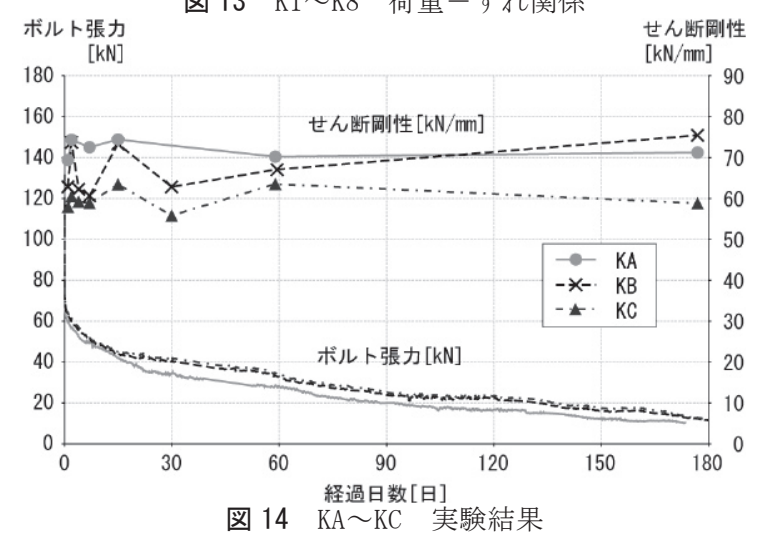

の差が大きくなる（23.8～29. 2kN） ため, 破壊形状は支圧部周辺破 断に安定することが推察できる。

\section{5. せん断特性の経時変化}

前節までの実験結果を参考にして, 時間経過がせん断特性に及ぼ す影響を調查する実験を行った。前節までの実験では, 実験を行な った $10 \mathrm{~mm} \leqq a \leqq 40 \mathrm{~mm}$ の範囲では, $20 \mathrm{kN}$ 耐力時のせん断剛性は $50 \mathrm{kN} / \mathrm{mm}$ 以上 $75 \mathrm{kN} / \mathrm{mm}$ 以下と安定したせん断剛性が確認された。そこで, 木 材圧縮部分にあらかじめ圧縮変形を与える必要のない最も大きな值 として, 全ての試験体の穴底厚さ $a$ を $15 \mathrm{~mm}$ とした。また本実験では, はしあき破断を回避するために, 図 12 に示すようにはしあき距離を $300 \mathrm{~mm}$ とした。 $(a=15, b=10, s=0.5, L=300$ とした場合，(2)式より $F_{1}=24.4 \mathrm{kN}$ ，(3) 式より $F_{2}=52.8 \mathrm{kN}$ である。）鋼板の寸法は $9 \mathrm{~mm} \times 120 \mathrm{~mm}$ $\times 600 \mathrm{~mm}$ としている。表 $2 ， 3$ 亿試験体一覧と実験結果を示す。試 験体は合計 11 体とした。試験体 K1 ～K8 は試験体作成からそれぞれ 1，2，4，7，15，30，60，180 日後にせん断実験を行い，破壊した。 また, 試験体 KA〜 KC は, 弾性領域内となるように荷重制御（最大荷 重 $7.5 \mathrm{kN})$ で, 試験体作成後日数をパラメータとして, 同一の試験 体に継続的に実験を行い，せん断剛性を測定した。

図 13 に K1 K8 のせん断力とずれ $\Delta$ の関係を示す。図 13 および表 2 より初期剛性（5〜10kN 耐力時）は時間が経過しても $57 \sim 86 \mathrm{kN} / \mathrm{mm}$ と安定している。しかし, ボルト張力と荷重降下点は次第に低下し ており,180 日経過したK8の実験時張力 $T_{\mathrm{t}}$ は $12 \mathrm{kN}$ であった(表 2 )。

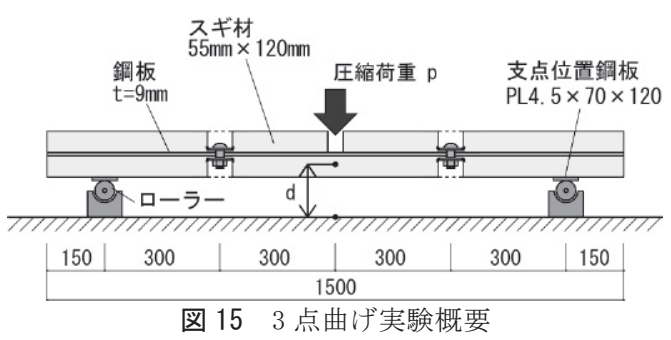

これは初期ボルト張力 $169 \mathrm{kN}$ の 7\%程度であり, 締付け 1 日後のボル 卜張力の約 $20 \%$ であった。K 8 の荷重降下点は $12 \mathrm{kN}$ であり，ボルト張 力と同值となっている。いずれの場合も明瞭なすべりは確認できな かった。一方，接合部の最大耐力は 29〜 $43 \mathrm{kN}$ (平均 33.8kN) で，経 過時間との相関関係は見られなかった。接合部の最大耐力は張力に 関係なく木材の耐力で決定されると推察できる。またす心゙ての試験 体の破壊形状は支圧部周辺破断であった。図 14 に KA〜 KC の実験結 果を示す。ボルト張力は締付け数時間で急激に低下するが，およそ 1 日経過後には安定し始め, その後接線勾配は緩やかになっている。 一方で， $7.5 \mathrm{kN}$ 耐力時割線剛性より得られたせん断剛性は締付け 180 日後において平均 $68 \mathrm{kN} / \mathrm{mm}$ であった。同一試験体に継続的に実 験を行った場合でも，時間経過の影響による初期せん断剛性への影 響は見られなかった。

\section{5. 複合断面柱軸力材の曲げ実験}

\section{1 . 3 点曲げ実験}

複合断面軸力材の弱軸まわり部材曲げ剛性を直接評価することを 目的として，図 15 に示す部材の 3 点曲げ実験を行った。断面寸法 $9 \mathrm{~mm} \times 120 \mathrm{~mm}$ の鋼板を, $55 \mathrm{~mm} \times 120 \mathrm{~mm}$ の無等級スギ材（いずれも長さ $1500 \mathrm{~mm} ）$ で挟み込んだもので，複合断面部材としての部材断面寸法 は $119 \mathrm{~mm} \times 120 \mathrm{~mm}$ である。接合箇所は部材中央から $300 \mathrm{~mm}$ の位置，2 点とし，鋼板表面は接合部せん断実験と同様に黒皮仕上げとした。 試験は ex1，ex2，ex3の 3 体に対して試験体作成 1 日後に行った。 一体化方法は図 6 と同じとし, 穴底厚さ $a$ は $15 \mathrm{~mm}$ とした。載荷方法 は弾性域内での荷重制御（最大荷重約 $1.5 \mathrm{kN}$ ）による 3 回の繰返し 静的載荷とした。軸力材に圧縮力が作用し座屈に至る曲げ変形が生 じる場合, 引張側の木材と鋼板の間には接触圧が作用して摩擦によ るせん断抵抗が発生するが，反対側の木材と鋼板の間には隙間が生 じ摩擦によるせん断抵抗は発生しないことを想定して，本実験では 上側の木材と鋼板の間に摩擦力が発生しない様に，木材中央部に $\phi$ 40 の穴を開け，治具を用いて鋼板中央部を直接載荷している。支点 間距離は $1200 \mathrm{~mm}$ (支点位置は中央から $600 \mathrm{~mm}$ の位置) であり, 試験 体とローラー支点の間には $4.5 \mathrm{~mm} \times 70 \mathrm{~mm} \times 120 \mathrm{~mm}$ の鋼板を挟み, 木材 のめり込みを緩和するよう配慮した。下側木材の上端付近から跳ね だした測定治具の鈶直変位を部材の面外曲げ変形として，台座に設 置したレーザー変位計で測定した。各試験体の材料定数を表 4 に示

表 43 点曲げ実験 試験体一覧，実験結果

\begin{tabular}{|c|c|c|c|c|c|c|c|c|c|c|c|}
\hline \multirow[b]{2}{*}{$\begin{array}{c}\text { 試験体 } \\
\text { 番号 }\end{array}$} & \multicolumn{3}{|c|}{ 試験体一覧 } & \multicolumn{7}{|c|}{ 実験結果 } & \multirow{5}{*}{$\begin{array}{l}E_{w}: \text { 木材繊維方向弾性係数, } \\
\mathrm{p}: \text { 荷重, d : 部材中央点変位, } \\
(\mathrm{EI})_{\mathrm{e}}: \text { 曲げ剛性 (実験結果), } \\
(\mathrm{EI})_{\mathrm{e} 35}: 35 \text { 日後曲げ剛性, } \\
\mathrm{EI}: \text { 曲げ剛性 (解析結果), } \\
\mathrm{n}: \mathrm{EI} /(\mathrm{EI})_{\mathrm{e}}\end{array}$} \\
\hline & $\begin{array}{c}\rho^{* 1)} \\
{\left[\mathrm{g} / \mathrm{cm}^{3}\right]}\end{array}$ & $\begin{array}{l}\mathrm{u}^{* 1)} \\
{[\%]}\end{array}$ & $\begin{array}{c}E_{w}^{* 1)} \\
{\left[k N / m^{2}\right]}\end{array}$ & $\begin{array}{c}\mathrm{p} / \mathrm{d} \\
{[\mathrm{kN} / \mathrm{mm}]}\end{array}$ & $\begin{array}{c}(\mathrm{EI})_{\mathrm{e}} \\
{\left[\mathrm{kN} \cdot \mathrm{m}^{2}\right]}\end{array}$ & $\begin{array}{r}(\mathrm{EI})_{\mathrm{e} 35} \\
{\left[\mathrm{kN} \cdot \mathrm{m}^{2}\right]} \\
\end{array}$ & $\begin{array}{c}\mathrm{T}_{1} \\
{[\mathrm{kN}]}\end{array}$ & $\begin{array}{c}\mathrm{T}_{35} \\
{[\mathrm{kN}]}\end{array}$ & $\begin{array}{c}\mathrm{T}_{35} / \mathrm{T}_{1} \\
{[\%]}\end{array}$ & 備考 & \\
\hline ex1 & 0.390 & 14.5 & 5.36 & 1.25 & 45.0 & 44.2 & - & - & - & ひずみ計測失敗 & \\
\hline ex2 & 0.380 & 13.8 & 5.41 & 1. 27 & 45.6 & 48.1 & 45 & 20 & 45 & & \\
\hline$e \times 3$ & 0.375 & 13.5 & 4.13 & 1.06 & 38.0 & 41.2 & 65 & 29 & 44 & & \\
\hline
\end{tabular}




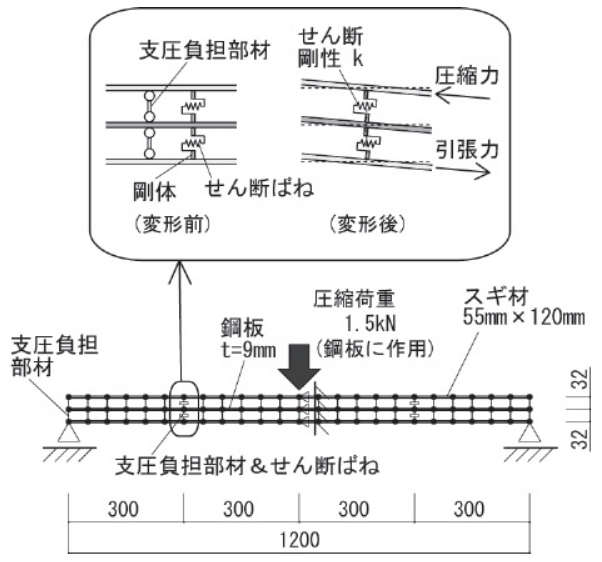

図 163 点曲げ実験 解析モデル

す。木材の繊維方向弾性係数は, 木材単体の 3 点曲げ実験より求め た。単純梁を 3 点曲げするとき, 全長にわたり等断面とみなした部 材の曲げ剛性 $(E I)_{e}$ は式(2)で表される。

$$
(E I)_{e}=\frac{p 1^{3}}{48 d}
$$

ただし $p$ は荷重, 1 は部材長さ, $d$ は部材中央点変位とする。各試験 体について, 実験より得られた $p / d$ の平均値と曲げ剛性 $(E I)_{e}$ を表 4 に示す。曲げ剛性の平均值は $42.9 \mathrm{kN} \cdot \mathrm{m}^{2}$ であった。

\section{2. 経時曲げ剛性の変化}

時間経過による木材の乾燥収縮やクリープに伴って, ボルト張力 が減少し, 曲げ剛性が変化する可能性がある。そこで, 1 度目の曲 げ実験から 35 日経過後に同一試験体 3 体に対して同条件で 3 点曲げ 実験を行った。2 度目の曲げ実験結果を表 4 中に示す。この時に計 測されたボルト張力は 1 度目の実験時の約 $45 \%$ であた。この結果 は 4 章の結果とほぼ整合する。35 日経過後の曲げ岡性は試験体作成 1 日後の曲嵝性の 1.04 倍であった。以上より，1 ケ月程度の時間 経過では，曲げ岡性への影響はほとんど無いことが確認できた。

\section{6. 解析による複合断面軸力材の曲げ剛性と座屈耐力の検討}

\section{1. 曲げ剛性}

本節では，汎用構造解析ソフト ${ }^{11)}$ を用いて提案複合断面部材の 2 次元数值モデルを作成し，解析值と実験值の比較を行う。

\section{1 ）数值モデルの作成方針}

1. 鋼部材と木部材を，それぞれ 1 本の線材でモデル化する。

2. 図 16 に示寸弾性せん断ばね要素を用いて接合部をモデル化する。 このせん断ばね要素では, 接合部の鋼板と木材の両方から剛な部 材を跳ね出し，その部材間にせん断ばねを配することで鋼木間の せん断変形（ずれ）を表現する。

3. 図 16 に示すように，鋼木間の接触を表現するために，鋼部材と

表 53 点曲げ実験 解析結果

\begin{tabular}{|c|c|c|c|c|c|c|}
\hline $\begin{array}{c}\text { 試験 } \\
\text { 体 } \\
\text { 番号 }\end{array}$ & \begin{tabular}{c}
$\mathrm{k}=50[\mathrm{kN} / \mathrm{mm}]$ のとき \\
\cline { 2 - 5 } \\
{$\left[\mathrm{EN} \cdot \mathrm{m}^{2}\right]$}
\end{tabular} & $\mathrm{n}$ & $\begin{array}{c}\mathrm{k}=75[\mathrm{kN} / \mathrm{mm}] \\
{\left[\mathrm{kN} \cdot \mathrm{m}^{2}\right]}\end{array}$ & $\mathrm{n}$ & $\begin{array}{c}(\mathrm{EI})_{\mathrm{p}} \\
{\left[\mathrm{kN} \cdot \mathrm{m}^{2}\right]}\end{array}$ & $\begin{array}{c}(\mathrm{EI})_{0} \\
{\left[\mathrm{kN} \cdot \mathrm{m}^{2}\right]}\end{array}$ \\
\hline \hline $\mathrm{ex} 1$ & 34.31 & 0.76 & 38.06 & 0.85 & 91.8 & 19.3 \\
\hline $\mathrm{ex2}$ & 34.47 & 0.76 & 38.24 & 0.84 & 92.6 & 19.5 \\
\hline $\mathrm{ex3}$ & 28.70 & 0.76 & 31.63 & 0.83 & 71.1 & 15.2 \\
\hline
\end{tabular}

$(E I)_{D}$ : 完全に一体化した場合の曲げ剛性，(EI)。：完全に別々に挙動する場合の曲げ剛性

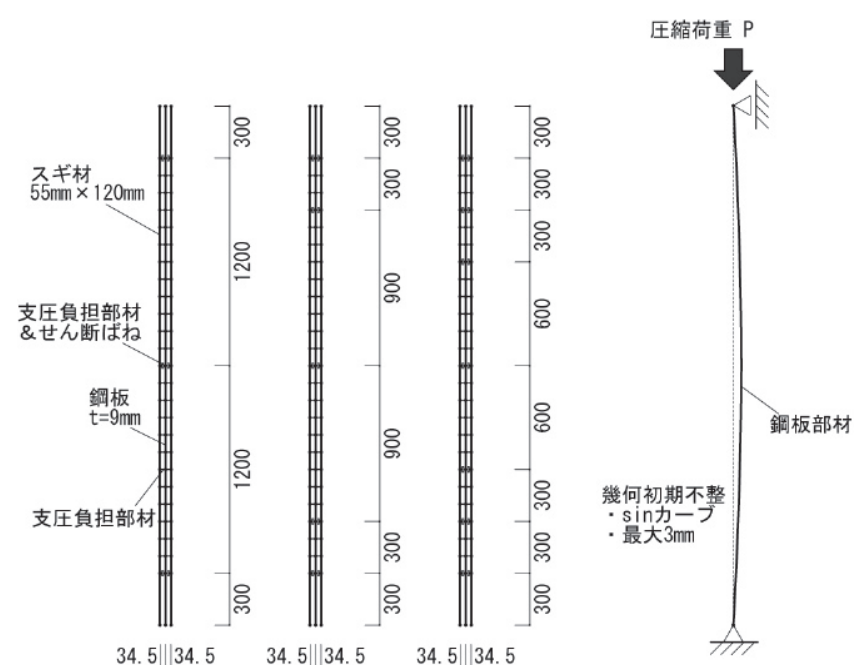

図 18 荷重・支持条件

木部材の間に圧縮力のみを負担するトラス要素を配置する。

4. 支圧負担部材に圧縮力が作用する箇所では, 鋼部材と木部材の回 転角が一致するよう拘束条件を与える。

\section{2 ）解析条件}

1. 鋼部材, 木部材の断面寸法はそれぞれ $9 \mathrm{~mm} \times 120 \mathrm{~mm}, 55 \mathrm{~mm} \times 120 \mathrm{~mm}$ とする。部材長は $1200 \mathrm{~mm}$ とする。

2. 材料定数は実験值を用いる。ただし，支圧負担部材は，支圧力は 材長方向にわたり分散し、支圧による板厚方向変形は局所的で、 はりせいに対するひずみは非常に小さいと考えられるため, 剛と 仮定し，材料定数は $1.0 \mathrm{E}+10 \mathrm{kN} / \mathrm{mm}^{2}$ とした。

3. 支持条件として, 両端部で鉛直変位のみ拘束し, 各部材中央で水 平変位のみ拘束する。

4. 固定荷重 $1.5 \mathrm{kN}$ を鋼部材中央点に作用させて弾性解析を行い, 曲 げ剛性 $E I$ を求める。

5. 一体化摩擦接合部のせん断剛性 $k$ は接合部せん断実験結果より 得られた 50〜 $75 \mathrm{kN} / \mathrm{mm}$ で分布すると仮定する。

\section{3 ) 結果と考察}

各試験体について，解析から得られた曲げ剛性 $E I$ および解析值 $E I$ を実験から得られた曲げ剛性 $(E I)_{e}$ で除して正規化した值 $n$ を表 5 に示す。どの試験体もほぼ同等の值となっており, 解析モデルは 80\%程度の精度で実験の曲げ剛性を評価できている。また, 完全に一 体化した場合（一体化接合部のせん断剛性がの）の曲げ岡性の理論 值 $(E I)_{p}$, 完全に独立して挙動する場合（一体化接合部のせん断剛 性が 0) の曲げ剛性の理論值 $(E I)_{0}$ をを同表に示す。解析值は完全に一 体化した場合の約 $1 / 3$, 完全に独立して挙動する場合の 2.7 倍程度 となった。

\section{2. 弾性座屈耐力}

本節では, 数值解析により, 実用規模の複合断面軸力材の座屈耐 力を弾性解析により評価する。接合部のせん断剛性と座屈耐力の関 係および座屈時に接合部に作用するせん断力を評価し，本研究にお ける一体化接合法を用いた軸力材の実用性を検討する。

\section{1) 解析条件}

本節では $P-\delta$ 効果を考慮した静的弾性増分解析を行い，材軸直交 


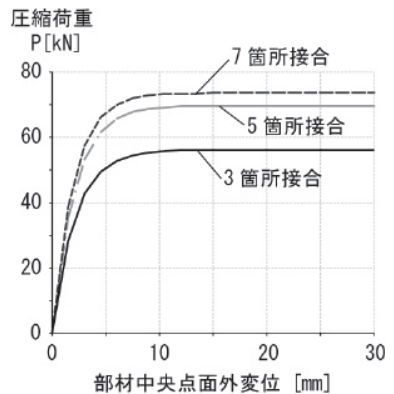

（i）圧縮荷重一中央点変位関倸

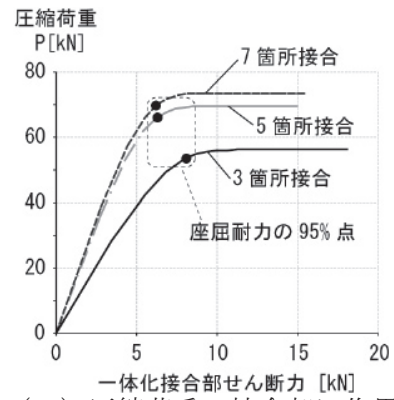

（ii）圧縮荷重一接合部に作用 する最大せん断力関係

図 19 解析結果 ( $\mathrm{k}=50$ のとき

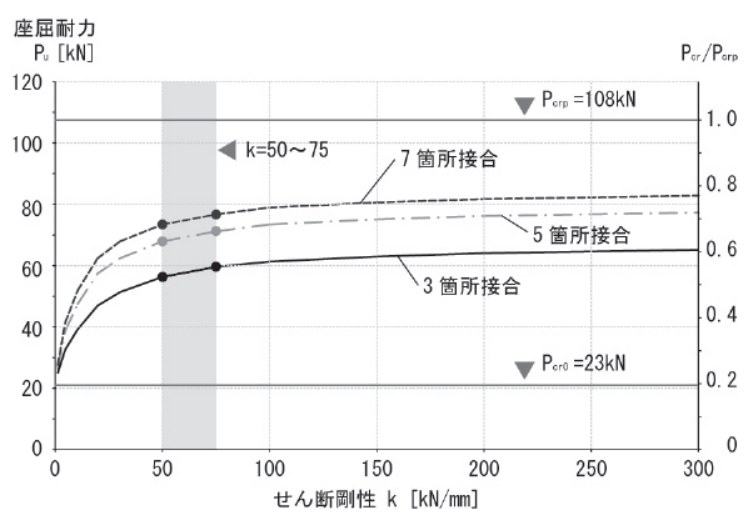

図 20 座屈荷重一せん断剛性関係

方向の変位量から定義した座屈耐力を算出する。解析条件を以下に 示す。

1. 鋼部材, 木部材の断面寸法はそれぞれ $9 \mathrm{~mm} \times 120 \mathrm{~mm}, 60 \mathrm{~mm} \times 120 \mathrm{~mm}$ とする。部材長を $3000 \mathrm{~mm}$ とする。

2. 一体化部分が 3, 5, 7 箇所の 3 つのモデルについてそれぞれ解析す る(図 17)。

3. 接合部位置を図 17 に示す。すべてのモデルについて部材端部か ら $300 \mathrm{~mm}$ の位置と部材中央点に接合部を設け，5,7 箇所モデルに 関しては，端部接合部位置から $300 \mathrm{~mm}$ 間隔で接合部を増設する。

4. 支持条件としては, 鋼板の下端で鉛直および水平変位を拘束し, 上端で水平変位を拘束する (図 18)。回転については拘束しない。

5. 幾何学的初期不整を弱軸方向に正弦曲線で与える (図 18)。不整 は部材中央部で最大值とし, 部材長の $1 / 1000^{12)}$ とする。

6. 解析条件は, 鋼板上端部に作用させた圧縮荷重 $P$ を漸増載荷し, 部材中央たわみが $\delta_{u}$ （部材長の $1 / 100$ として $30 \mathrm{~mm}$ とする。）に 達した時の $P$ を座屈耐力 $P_{u}$ と定義する。

7. 材料定数は公称值を用いる。鋼部材の弾性係数 $205 \mathrm{kN} / \mathrm{mm}^{2}$, 木 部材（スギ）の繊維方向弾性係数 $4.5 \mathrm{kN} / \mathrm{mm}^{2}$ とする。

表 6 座屈解析結果

\begin{tabular}{|c|c|c|c|c|c|c|c|}
\hline 接 & \multicolumn{3}{|c|}{$\mathrm{P}_{\mathrm{u}}[\mathrm{kN}]$} & \multicolumn{2}{|c|}{$\mathrm{p}$} & \multicolumn{2}{|c|}{$Q[\mathrm{kN}]$} \\
\cline { 2 - 8 } $\begin{array}{c}\text { 合 } \\
\text { 筫 } \\
\text { 所 }\end{array}$ & $\begin{array}{c}\mathrm{k}=50 \\
{[\mathrm{kN} / \mathrm{mm}]}\end{array}$ & $\begin{array}{c}\mathrm{k}=75 \\
{[\mathrm{kN} / \mathrm{mm}]}\end{array}$ & $\begin{array}{c}\mathrm{k}=1 \mathrm{E}+10 \\
{[\mathrm{kN} / \mathrm{mm}]}\end{array}$ & $\begin{array}{c}\mathrm{k}=50 \\
{[\mathrm{kN} / \mathrm{mm}]}\end{array}$ & $\begin{array}{c}\mathrm{k}=75 \\
{[\mathrm{kN} / \mathrm{mm}]}\end{array}$ & $\begin{array}{c}\mathrm{k}=50 \\
{[\mathrm{kN} / \mathrm{mm}]}\end{array}$ & $\begin{array}{c}\mathrm{k}=75 \\
{[\mathrm{kN} / \mathrm{mm}]}\end{array}$ \\
\hline \hline 3 & 56.3 & 59.4 & 67.8 & 0.80 & 0.78 & 8.04 & 9.14 \\
\hline 5 & 68.0 & 71.4 & 79.6 & 0.76 & 0.75 & 6.22 & 8.09 \\
\hline 7 & 73.6 & 78.0 & 85.5 & 0.80 & 0.79 & 6.26 & 7.16 \\
\hline
\end{tabular}

$\mathrm{P}_{\mathrm{u}}$ : 座屈耐力, $\mathrm{p}: 95 \%$ 座屈耐力時に鋼材が負担する軸力の割合,

Q: 95\%座屈耐力時に一体化接合部に作用する最大せん断力（必要せん断耐力）

$k$ : せん断剛性

8. 一体化接合部のせん断剛性 $k$ をパラメータとして解析を行う。

\section{2 ) 結果と考察}

図 19 に解析結果の一例として, 接合部箇所が 3 箇所で, せん断剛 性 $k$ が $50 \mathrm{kN} / \mathrm{mm}$ の場合における圧縮荷重一部材中央点水平方向変位 関係および圧縮荷重一接合部に作用する最大せん断力関係を示す。

同図より部材中央点水平方向変位が $30 \mathrm{~mm}$ に達したとき柱の圧縮 荷重は一定值に漸近していると考えられることから，このときの圧 縮荷重を座屈耐力と定義する。また本論文における接合部に作用す るせん断力については，曲げ変形が進行するとせん断力は増大する が，座屈耐力時では必要とされるせん断耐力（以下，必要せん断耐 力とする）を過大評価することになると考え，圧縮荷重が座屈耐力 の 95\%のときを必要せん断耐力として定義し，実験で得られた接合 部荷重降下点と比較する。

せん断剛性と座屈耐力の関係を図 20 に示す。せん断剛性と一体化 部分の個数の増大に応じて座屈耐力は増加するが, 増大の程度は小 さくなる傾向にある。せん断剛性 $\mathrm{k}$ をめに近づけると, 座屈耐力は, 一体化部分が 3 個の場合 $67.8 \mathrm{kN}$ に, 5 個の場合は $79.6 \mathrm{kN}$ に, 7 個の 場合は $85.5 \mathrm{kN}$ に漸近する。なお複合断面が完全に一体化していると 仮定した場合の弾性座屈耐力 $P_{\text {crp }}$ は $107.5 \mathrm{kN}$ ，鋼材と木材が完全に 別々に挙動する場合の弾性座屈耐力 $P_{c r 0}$ は $23.5 \mathrm{kN}$ となる。参考のた め, これらの座屈耐力の值も図中に示寸。図 20 より, 一体化部分の 個数を多くすると, 座屈耐力は $P_{c r p}$ に近付き, せん断剛性を小さく すると座屈耐力は $P_{c r 0}$ に近付くことが分かる。解析結果を表 6 に示 す。一面せん断試験より得られたせん断剛性の值（50～ $75 \mathrm{kN} / \mathrm{mm} ） を$ 用いた場合, 接合部が 3 箇所ならば, 座屈耐力は $56.3 \sim 59.4 \mathrm{kN}$ とな り，完全に一体化した複合断面の座屈耐力と比較して $0.52 \sim 0.55$ 倍の耐力となる。また，接合部が 5 箇所の場合は $0.63 \sim 0.66$ 倍， 7 箇所の場合は $0.68 \sim 0.72$ 倍となる。また鋼材と木材が完全に別々に 挙動する場合と比較すると，それぞれ 2.45～2. 58 倍，2.96〜3.10 倍，3. 20〜3. 35 倍となった。なお $120 \mathrm{~mm}$ 角スギ材の弾性座屈耐力は 85. $3 \mathrm{kN}$ で，この值に対して解析モデルの弱軸まわりの座屈耐力は 0. 66 0.91 倍となる。一方で複合断面軸力材の強軸まわりの座屈耐 力は $376.6 \mathrm{kN}$ で, $120 \mathrm{~mm}$ 角スギ材の 4.42 倍となる。木質構造では一 般的に接合部の耐力確保や, 部材の曲げ剛性確保のために断面が決 まることが多い。本提案接合部材は，鋼材部分同士を接合すること により，柱梁接合部の強度確保が容易であること，強軸まわりの曲 げ剛性は大きく増大することといった利点がある。弱軸まわりの座 屈耐力は $120 \mathrm{~mm}$ 角スギ材の弾性座屈耐力を下回るが，弱軸まわりの みを構造用合板等で座屈補剛することは容易であるため，短所が長 所を上回る実用的な部材といえる。また，図 20 より，50kN/mm 以上 のせん断剛性が確保できれば，せん断ばね定数の変化に対する座屈 耐力の変化は小さいことが分かる。95\%座屈耐力時に鋼材が負担する 軸力の割合を同表に示す。鋼材が負担する軸力は約 $80 \%$ であった。

せん断剛性が $50 \mathrm{kN} / \mathrm{mm}$ および $75 \mathrm{kN} / \mathrm{mm}$ の場合の必要せん断耐力を 表 6 に示す。いずれの值も 4 章で行った 180 日以内の経時降下を考 慮したせん断実験結果の荷重降下点を下回っており，接合部に必要 とされるせん断耐力が提案接合方法で確保されていると考えられる が，余裕率は小さく（3 箇所接合， $\mathrm{k}=75 \mathrm{kN} / \mathrm{mm}$ の場合で，0.24), さ らなる経時の影響により耐力不足になる可能性もある。今後の課題 としてこれらを検討する必要がある。 


\section{7. 結論}

本研究により得られた知見を以下に整理する。

（1）鋼板を木材で挟み，トルシア形高力ボルトにより一体化する摩 擦接合法とそれを用いた鋼木複合断面軸力材を提案した。提案 複合断面軸力材に必要な加工は, 鋼材の穴あけ加工, 木材の座 掘穴あけ加工，トルシア形高力ボルトによる締付のみであり， 加工性に優れていると考えられる。

（2）鋼材とスギ材からなる 15 体の接合部試験体を試作し，トルシア 形高力ボルトを用いてピンテールが破断するまでボルト張力を 導入することで, スギ材に $70 \%$ 前後の繊維直行方向の圧縮ひずみ 度を安定して与えられることを例証した。

(3) $120 \mathrm{~mm} \times 9 \mathrm{~mm}$ の鋼材を $120 \mathrm{~mm} \times 60 \mathrm{~mm}$ のスギ材で挟み, $\mathrm{S} 10 \mathrm{~T} ・ \mathrm{M} 20$ のトルシア形高力ボルトで締結した接合部の一面せん断実験を 行った。その結果, 座掘り穴底厚さ（図6の a) が約 $10 \mathrm{~mm}$ から $40 \mathrm{~mm}$ までの範囲において, 試験体作成即時において, 提案接合 法により $20 \mathrm{kN}$ 以上のせん断耐力と, せん断荷重が $20 \mathrm{kN}$ の時の 割線剛性として $50 \mathrm{kN} / \mathrm{mm}$ 以上 $75 \mathrm{kN} / \mathrm{mm}$ 以下のせん断剛性（平均 $61 \mathrm{kN} / \mathrm{mm}$ ) が確保できた。また経時変化が接合部の力学的特性に 及ぼす影響を計測した。初期剛性や最大耐力の変化は比較的小 さかったが，ボルト張力や荷重降下点の低下が認められた。今 後さらに経時の影響を調べていく必要がある。

（4）上記せん断実験とほぼ同一の断面（120mm×9mm の鋼材と $120 \mathrm{~mm}$ $\times 55 \mathrm{~mm}$ のスギ材で構成) を持ち, 長さが $1500 \mathrm{~mm}$ で 2 個の接合部 を持つ複合断面軸力材の 3 点曲げ実験を行い，その弱軸まわり の曲げ剛性を評価した。またこの複合断面軸力材の数值モデル を作成し, 接合部のせん断試験から得られたせん断剛性を数值 モデルに適用して複合断面軸力材の弱軸まわりの曲げ剛性を予 測した。その結果，実験值を $80 \%$ 程度の精度で予測できた。

（5）複合断面軸力材の曲げ剛性の経時変化を実験により調べた結果, 1 ケ月程度ではどちらの剛性の変化も無視できるほど小さかっ た。

（6）提案部材の実用性を検討するため，一例として実用規模の寸法 の複合断面軸力材の数值モデルを作成し, 接合部のせん断剛性 と部材の座屈耐力の関係を評価した。その結果, 座屈時に一体 化接合部のせん断力は荷重降下点に達していないことが確認で きた。また，せん断剛性が $50 \mathrm{kN} / \mathrm{mm}$ 程度確保できれば，それ以 上にせん断岡性を大きくしても座屈耐力は大きく変化しないと いう知見を得た。

今後の課題として，一体化接合部の経時変化による影響をさらに 調査することが必要である。

\section{謝辞}

本研究は, 平成 21 年度文部科学省科学研究費補助金 (若手研究 (B) 課題研究番号 21760438, 研究代表者: 高木次郎) および(財)トステ 么建材産業振興団「第 18 回 (平成 21 年度) 研究助成」(研究代表者: 高木次郎）の下で実施した。また, 清水建設（元京都大学大学院生） の新木郁生氏には実験と解析に関して, 京都大学の吉田亘利氏には 実験に関して多大な協力を得た。ここに記して謝意を表す。

\section{参考文献}

1）楠寿博，津村千香子，金子洋文，杉内章浩，奥野智久：木材と鋼板を組 み合せた合成部材の圧縮強度実験，日本建築学会大会学術講演梗概集．構 造III (C-1) , pp. 61-62, 2001.9

2) 楠寿博, 津村千香子, 杉内章浩, 奥野智久 : 木材と鋼板を組み合せた合 成部材の圧縮強度実験（その 2 ），日本建築学会大会学術講演梗概集。構 造III (C-1) , pp. 163-164, 2002.8

3）杉内章浩, 津村千香子, 楠寿博, 奥野智久 : 木材と鋼板を組み合せた合 成部材の圧縮強度実験（その 3 : 理論的検討）, 日本建築学会大会学術講 演梗概集。構造III（C-1），pp. 165-166，2002.8

4）堀井健史, 坂田弘安, 竹内徹, 鈴木達人, 中村博志 : シアリング接合を 用いた杉集成材と鋼板によるハイブリッド部材の力学的挙動に関する実験 研究，日本建築学会構造系論文集，第 584 号，pp. 125-132，2004. 10

5）坂田弘安，堀井健史，竹内徹，中村博志，松田和浩：シアリング接合部 の木材繊維方向せん断性能に関寸る実験研究, 日本建築学会構造系論文集, 第 627 号, pp. 773-779，2008.5

6）坂田弘安, 上角充広, 富本淳, 中村泰教 : 摩擦接合型コネクタを用いた スギー鋼板ハイブリッド部材の軸方向特性，日本建築学会構造系論文集， 第 627 号, pp. 811-817, 2008.5

7）坂田弘安，上角充広，富本淳，中村泰教：摩擦接合型コネクタを用いた スギ集成材と鋼板接合部のせん断性能に関する実験研究，日本建築学会構 造系論文集，第 643 号，pp. 1659-1664，2009.9

8） 木質構造設計基準・同解説 一許容応力度・許容耐力設計法一，日本建築 学会, 2006

9）鉄骨工事技術指針・工事現場施工編，日本建築学会，2007

10）木材工業ハンドブック，林業試験場，1991

11） MIDAS IT : MIDAS/Gen ユーザーマニュアル，第 2 巻 Analysis \& Design 解析と設計に関する解説， 2002

12）鋼構造座屈設計指針，日本建築学会，2009

\section{APPENDIX}

複合断面が完全に一体化していると仮定した場合の弾性座屈荷重 $P_{c r p}$, 鋼材 と木材が完全に別々に挙動する場合の弾性座屈荷重 $P_{c r 0}$ は次式を用いて算出 される。

$$
\begin{aligned}
& P_{c r i}=\frac{\pi^{2}(\mathrm{EI})_{i}}{I_{k}} \\
& (E I)_{p}=E_{s} I_{s}+2 E_{w}\left(I_{w}+A_{w} e^{2}\right) \\
& (E I)_{0}=E_{s} I_{s}+2 E_{w} I_{w}
\end{aligned}
$$

ただし， $I_{k}$ は座屈長さ， $E_{s}, E_{w}$ は鋼材，木材のヤング係数， $I_{s}, I_{w}$ は鋼材，木 材の断面二次モーメント, $A_{w}$ は木材の断面積, $e$ は鋼材と木材の部材中心間 距離とする。

（2010年 5 月10日原稿受理，2010年11月29日採用決定） 